\title{
Effect of Different Surface Finishing Methods and Colorant Solutions on Translucency of Monolithic CAD/CAM Ceramics
}

\author{
Farklı Yüzey Bitirme Iş̧lemlerinin ve Renklendirici Solüsyonların \\ Monolitik CAD/CAM Seramiklerin Translüsensisi Üzerine Etkisi \\ (D) Yeliz Hayran, (D) Işıl Sarıkaya
}

Tokat Gaziosmanpaşa University Faculty of Dentistry, Department of Prosthodontics, Tokat, Turkey

Keywords

Ceramics, color, dental porcelain, opalescence

Anahtar Kelimeler

Seramikler, renk, dental porselen, opelesans

Received/Geliş Tarihi : 27.04.2018

Accepted/Kabul Tarihi : 26.07.2018

doi:10.4274/meandros.galenos.2018.85570

Address for Correspondence/Yazışma Adresi: Yeliz Hayran MD,

Tokat Gaziosmanpaşa University Faculty of Dentistry, Department of Prosthodontics,

Tokat, Turkey

Phone : +90 3562124222

E-mail : yeliz.hayran@gop.edu.tr

ORCID ID: orcid.org/0000-0002-8664-9083

(C) Meandros Medical and Dental Journal, Published by Galenos Publishing House.

This is article distributed under the terms of the Creative Commons Attribution NonCommercial 4.0

International Licence (CC BY-NC 4.0).

\begin{abstract}
Objective: An ideal aesthetic restoration should be morphologically and optically compatible with the natural teeth and, at the same time, biologically acceptable. The translucency of the restoration is the most important factor in achieving a natural tooth appearance. The aim of this study was to compare the translucency parameters (TPs) of two types of monolithic computer-aided design/computeraided manufacturing (CAD/CAM) ceramics, Vita Suprinity HT (VS) and IPS e.max CAD HT (IPS), after utilizing three different surface finishing methods and being exposed to cola, coffee, and black tea solutions.

Materials and Methods: A total of 24 groups consisting of 10 samples each were created from VS and IPS e.max CAD ceramics. Glaze, Shofu polishers, and Sof-lex polishing discs were used to finish the surface of the ceramics. Cola, coffee, and black tea were used as coloring solutions. For the control groups, samples were kept in distilled water. The TP was determined for optical properties. Data were statistically analyzed using three-way analysis of variance (ANOVA). The Bonferroni test was used for multiple comparisons.

Results: Material, method, group and interaction effects were found statistically significant $(p<0.001)$. There was a statistically significant difference in TP value between the materials in terms of applied surface treatments $(p<0.05)$. The TP value for each group was different for the exposed solutions after surface finishing $(p<0.05)$.

Conclusion: Translucency was affected by type of the monolithic CAD/CAM ceramic material used. The translucency of the VS ceramic was found to be higher than the IPS ceramic. Colorant solutions decreased the translucency of all ceramics. The lowest TP value for the IPS group was observed in the samples exposed to cola, while for the VS group it was observed in the samples exposed to black tea. The IPS ceramic finished with Sof-lex and the VS ceramic finished with Shofu exhibited higher translucency values.
\end{abstract}

Öz

Amaç: İdeal bir estetik restorasyon, doğal dişlerle morfolojik ve optik olarak uyumlu aynı zamanda biyolojik olarak kabul edilebilir olmalıdır. Restorasyonun translüsensisi doğal diş görünümü için en önemli faktördür. Bu çalışmanın amacı, Vita Suprinity HT (VS) ve IPS e.max bilgisayar destekli tasarım (CAD) HT (IPS) olmak 
üzere iki tip monolitik CAD bilgsayar destekli üretim (CAM) seramiğine üç farklı yüzey sonlandırma işleminin uygulanmasının ardından kola, kahve ve siyah çaya maruz bırakılarak seramiklerin translüsensi parametresini (TP) karşılaştırmaktır.

Gereç ve Yöntemler: VS ve IPS e.max CAD seramiklerinden her birinde 10 örnekten oluşan toplam 24 grup oluşturuldu. Seramiklerin yüzeyini bitirmek için glaze, Shofu polisajları ve Sof-lex polisaj diskleri kullanıldı. Renklendirme çözeltisi olarak kola, kahve ve siyah çay seçildi. Kontrol grupları için, örnekler damıtılmış suda tutuldu. Optik özellikler için TP belirlendi. Veriler, üç yönlü varyans analizi kullanılarak istatistiksel olarak analiz edildi. Çoklu karşılaştırma için Bonferroni testi kullanıldı.

Bulgular: Materyal, yöntem, grup ve etkileşim etkileri istatistiksel olarak anlamlı bulundu $(p<0,001)$. Uygulanan yüzey işlemleri açısından materyaller arasında TP değerinde istatistiksel olarak anlamlı fark vardı $(p<0,05)$. Her bir grup için TP değeri, yüzey bitirme işlemi sonrası maruz bırakılan çözeltiler açısından farklıydı $(p<0,05)$.

Sonuç: Translüsensi, monolitik CAD/CAM seramik tiplerinden etkilenmiştir. VS seramiğin translüsensisi IPS seramikten daha yüksek bulunmuştur. Renklendirici solüsyonlara maruz bırakılan seramik gruplarının TP'si azaldı. IPS grubu için en düşük TP değeri kolaya maruz kalan örneklerde gözlenirken, VS grubu için siyah çaya maruz kalan örneklerde gözlenmiştir. Sof-lex ile bitirilen IPS seramik ve Shofu ile tamamlanmış VS seramik yüksek translüsensi değerleri sergiledi.

\section{Introduction}

The search for the ideal anterior ceramic material has accelerated, with the increase in the aesthetic expectations of patients in recent years. An ideal aesthetic restoration should be morphologically and optically compatible with the natural teeth and biologically acceptable. All ceramic restorations offer an aesthetic appearance close to the natural optical properties of the tooth structure $(1,2)$. However, it is necessary to provide harmony with the neighboring teeth for a natural appearance, but this desired natural appearance is not always achievable due to difficulties in matching the natural tooth color with the existing tooth porcelains $(3,4)$. Hue, chroma, value, and translucency/opacity are color elements that affect the aesthetics of dental restorations $(5,6)$. The translucency of the restoration is the most important factor in achieving a natural tooth appearance (7-10). Since human enamels have a natural translucency, aesthetic materials must reproduce the translucency of natural teeth $(11,12)$. Especially for younger individuals, aesthetic ceramics must have high translucency in order to mimic the natural tooth structure (13). The translucency parameter (TP) and contrast ratio $(C R)$ are used to measure translucency of dental materials (14). A high TP indicates that the material is less opaque (15). Also, the ceramic materials of fixed dental prostheses must provide long-term color stability to avoid repeated restoration.

The surface finishing affects many aspects of the final restoration, such as staining, the degree of color change, plaque buildup, and the wear resistance of ceramics $(16,17)$. Food and other residues will stick to the surface, if a restoration presents a rough surface. It has been shown that significant color change occurs on rough surfaces (18). The surface cracks that develop during the preparation of the restoration are reduced by the polishing process (19). Therefore a dental restoration should have a highly polished surface due to this aesthetic, mechanical, and biological considerations.

When choosing an all-ceramic system, factors, such as the color of the ceramic material and neighboring teeth and the forces foreseen in that area, should be considered $(20,21)$. For example, the fragile structure of conventional glass ceramics limits the use of these ceramics in the posterior area (22). The use of zirconia as a core material has improved the mechanical properties of all ceramic restorations, but zirconia copings need to be a coated with a ceramic application to attain proper aesthetics $(23,24)$. With the widespread use of dental computer-aided design/ computer-aided manufacturing (CAD/CAM) systems, various ceramics offering both durable and optimal aesthetics have been introduced into the dental market. One of these is monolithic glass-ceramics, which was developed to provide aesthetics without the need for coating ceramics (25). Elimination of the connection between the core and the coating ceramic can make the restoration more structurally sound and longer-lasting $(26,27)$. Lithium disilicate ceramic restoration is one of the most popular monolithic ceramic systems for anterior and posterior single crowns and partial veneered restorations because of its favorable physical properties (28). However, the durability of this ceramic in the posterior region may not be optimal (29-31). Recently, zirconia-reinforced lithium silicate glass-ceramics were introduced for inlays, onlays, implant abutments, and partial and full 
crowns manufactured using the CAD/CAM system. Zirconia particles are included to strengthen the ceramic build (32).

To the best of the authors' knowledge, no information is available on the clinical and laboratory translucency change of monolithic CAD/CAM ceramics subjected to different surface finishing methods and immersed in coloring solutions, such as cola, coffee, and black tea. Therefore, the aim of this study was to compare the TP of two types of monolithic CAD/CAM ceramics, the Vita Suprinity HT (VS) and the IPS e.max CAD HT (IPS), after three different surface finishing methods and exposure to cola, coffee, and black tea solutions. The null hypothesis was that the type of surface finishing and all colorant solutions would not affect the translucency of the monolithic CAD/CAM ceramics.

\section{Materials and Methods}

\section{Preparation of Samples}

Two monolithic CAD/CAM ceramics, including a zirconia-reinforced lithium silicate ceramic (VS, Vitazahnfabrik) and a lithium disilicate ceramic (IPS e.max CAD, Ivoclar, Vivadent AG) were evaluated (Table 1).

Ceramic blocks were cut at 150 rpm using a precision cutting machine (Micracut 201, Bursa, Turkey) with a diamond disc to render a sample thickness of $1.2 \mathrm{~mm}$. Both ceramic materials were divided into three main groups and control group $(n=40)$ for the three different surface finishing methods: glaze, sandpaper discs (Soflex), and silicone-carbide rubber points (Shofu). After the surface treatments, each group was divided into four subgroups according to the exposed solutions: distilled water (control), cola, coffee, and black tea solutions. A total of 240 specimens were prepared, 10 in each group $(n=10)$. After the blocks were cut, all samples were subjected to the crystallization cycle according to the manufacturer's instructions. Then, both surfaces of the samples were sanded with 600,800 , and 1.200 grained silicon carbide abrasives (English Abrasives, London, UK) under water cooling at $100 \mathrm{rev} / \mathrm{min}$ before surface treatments were applied. Each ceramic material received one coat of glaze according to the manufacturer's instructions (Vita akzent plus glaze, Vita, Germany and IPS Empress Universal glaze, Ivoclar, Vivadent). For the specimens to be surface treated with Sof-lex, Sof-lex polishing discs (Sof-lex polishing discs, 3M ESPE, St.Paul, ABD) with a diameter of $12.7 \mathrm{~mm}$ were used in accordance with the manufacturer's recommendation. Polishing was first carried out at $10.000 \mathrm{rpm}$ with thick and medium discs, and then followed with thin and superthin discs. For the specimens to be surface treated with Shofu, first, a white stone (Dura-white Stone, Shofu, Japan), and, then, three silicone-carbide rubber points (Ceramiste Standard, Ultra and Ultra II, Shofu, Japan) were used, respectively, for smoothing the surface. Polishing operations were performed by the same applicator using a low-speed rotary hand tool (Kavo Ewl 4990; KaVo Dental Gmbh, Germany). Sample thicknesses were checked with a digital caliper (Absolute Digimatic, Mitutoyo, Japan). After polishing, all samples were sterilized for $10 \mathrm{~s}$ using distilled water in an ultrasonic cleaner (Pro-Sonic 600; Sultan Healthcare, NJ, USA), and then air-dried. The groups were formed by random selection of the ten samples for each group. The groups are shown in Table 2. I1a, 12a, I3a, V1a, V2a, and V3a served as the control groups.

\section{Preparation of Colorant Solutions}

Each of colorant solutions were prepared for consumption 5 cups per day. Instant coffee sticks

\begin{tabular}{|c|c|c|c|}
\hline Material & Chemical composition & Code & Manufacturer \\
\hline IPS e.max CAD (A2-HT) & $\begin{array}{l}\text { Lithium disilicate glass-ceramic } \\
\left(58-80 \% \mathrm{SiO}_{2}, 11-19 \% \mathrm{Li}_{2} \mathrm{O}, 0-13 \% \mathrm{~K}_{2} \mathrm{O}, 0-5 \% \mathrm{MgO}, 0-8 \% \mathrm{ZrO}_{2}, 0-8 \%\right. \\
\left.\mathrm{ZnO}, 0-11 \% \mathrm{P}_{2} \mathrm{O}_{5}, 0-5 \% \mathrm{Al}_{2} \mathrm{O}_{3}, 0-8 \% \text { colouring oxides}\right)^{*}\end{array}$ & IPS & $\begin{array}{l}\text { Ivoclar Vivadent } \\
\text { AG }\end{array}$ \\
\hline Vita suprinity (2M2-HT) & $\begin{array}{l}\text { Zirconia reinforced lithium silicate glass-ceramic } \\
\left(56-64 \% \mathrm{SiO}_{2}, 15-21 \% \mathrm{Li}_{2} \mathrm{O}, 1-4 \% \mathrm{~K}_{2} \mathrm{O}, 3-8 \% \mathrm{P}_{2} \mathrm{O}_{5}, 1-4 \% \mathrm{Al}_{2} \mathrm{O}_{3}, 8-12 \%\right. \\
\left.\mathrm{ZrO}_{2}, 0-4 \% \mathrm{CeO}_{2}, 0-6 \% \text { pigments }\right)^{*}\end{array}$ & VS & Vita Zahnfabrick \\
\hline
\end{tabular}




\begin{tabular}{|l|l|l|l|l|}
\hline Table 2. Groups in the study \\
\hline Materials & Surface finishing and colorant solution groups \\
\hline \multirow{4}{*}{ IPS (I) } & $\begin{array}{l}\text { Glaze + distilled water } \\
\text { I1a }\end{array}$ & $\begin{array}{l}\text { Glaze + cola } \\
\text { I1b }\end{array}$ & $\begin{array}{l}\text { Glaze + tea } \\
\text { I1 }\end{array}$ & $\begin{array}{l}\text { Glaze + coffee } \\
\text { I1 }\end{array}$ \\
\cline { 2 - 5 } & $\begin{array}{l}\text { Sof-lex + distilled water } \\
\text { I2a }\end{array}$ & $\begin{array}{l}\text { Sof-lex + cola } \\
\text { I2b }\end{array}$ & $\begin{array}{l}\text { Sof-lex + tea } \\
\text { I2c }\end{array}$ & $\begin{array}{l}\text { Sof-lex + coffee } \\
\text { I2d }\end{array}$ \\
\cline { 2 - 5 } & $\begin{array}{l}\text { Shofu + distilled water } \\
\text { I3a }\end{array}$ & $\begin{array}{l}\text { Shofu + cola } \\
\text { I3b }\end{array}$ & $\begin{array}{l}\text { Shofu + tea } \\
\text { I3c }\end{array}$ & $\begin{array}{l}\text { Shofu + coffee } \\
\text { I3d }\end{array}$ \\
\hline \multirow{5}{*}{ VS (V) } & $\begin{array}{l}\text { Glaze + distilled water } \\
\text { V1a }\end{array}$ & $\begin{array}{l}\text { Glaze + cola } \\
\text { V1b }\end{array}$ & $\begin{array}{l}\text { Glaze + tea } \\
\text { V1c }\end{array}$ & $\begin{array}{l}\text { Glaze + coffee } \\
\text { V1d }\end{array}$ \\
\cline { 2 - 5 } & $\begin{array}{l}\text { Sof-lex + distilled water } \\
\text { V2a }\end{array}$ & $\begin{array}{l}\text { Sof-lex + cola } \\
\text { V2b }\end{array}$ & $\begin{array}{l}\text { Sof-lex + tea } \\
\text { V2c }\end{array}$ & $\begin{array}{l}\text { Sof-lex + coffee } \\
\text { V2d }\end{array}$ \\
\cline { 2 - 5 } & $\begin{array}{l}\text { Shofu + distilled water } \\
\text { V3a }\end{array}$ & $\begin{array}{l}\text { Shofu + cola } \\
\text { V3b }\end{array}$ & $\begin{array}{l}\text { Shofu + tea } \\
\text { V3c }\end{array}$ & $\begin{array}{l}\text { Shofu + coffee } \\
\text { V3d }\end{array}$ \\
\hline
\end{tabular}

(Nescafe Classic, Nestle, Bursa, Turkey) and tea bags (Earl Grey, Doğuş, Ordu, Turkey) were used in the study and prepared according to the manufacturer's suggested concentrations. The $18.5 \mathrm{~g} \times 5$ coffee sticks were added to $1 \mathrm{~L}$ of boiled distilled water. To prepare the tea solution, $10 \mathrm{~g} \times 5$ black tea bags were added to $1 \mathrm{~L}$ of boiled water and allowed to steep for $3 \mathrm{~min}$. A one L cola (Coca-Cola, Coca-Cola Co, İstanbul, Turkey) solution was used in the same manner.

\section{Coloring Methods}

Distilled water was used for the control group in the study. The samples were stored in cola, coffee, and black tea, distilled water solutions in the incubator at $37 \pm 1{ }^{\circ} \mathrm{C}$. As $144 \mathrm{~h}$ corresponds to about six months of coffee consumption (33), all sample groups were exposed to the relevant solutions for $144 \mathrm{~h}$ to ensure standardization. After removal from the colorant solutions, the samples were washed with distilled water for five min, and then dried.

\section{Color Measurements}

Color measurements were performed before and after exposure to the solutions after surface treatments were applied. Color measurements were made with a clinical spectrophotometer (Vita Easy Shade Advance, Vita Zahnfabrik, Germany) using a black and white background under D65 lighting conditions. Translucency values of the samples were determined by the TP according to the CIE L* $a * b$ * system. For the translucency measurement, the formula TP $=[(L * B-L * W) 2+(a * B-a * W) 2+(b * B-b$ $*$ W) 2] $1 / 2$ was used. Data's were statistically analyzed using three-way analysis of variance (ANOVA). The Bonferroni test was used for multiple comparisons.
The SPSS (Statistical Package for the Social Sciens) for Windows computer program was used for statistical analyses. Material, method, group and interaction effects were considered to be significant $(p<0.001)$.

\section{Results}

The TP values obtained for each group are summarized in Table 3. When a material has a TP of 100, TP is considered transparent; a TP of 0 indicates that the material is opaque. TP shows the color difference ( $D E^{*}$ ) on a black and white background of a material of the same thickness and is calculated with the color difference formula (14). A color difference equal to zero $\left(D E^{*}=0\right)$ describes a non-translucent material with excellent masking properties (34).

Material, method, group and interaction effects were found statistically significant $(p<0.001)$. There was a statistically significant difference in Total TP value between the materials in terms of applied surface treatments $(p<0.05)$. The ranking of the TP values of materials for control group after the surface finishing process from highest to lowest was Sof-lex $>$ Glaze $=$ Shofu for IPS and Shofu > Sof-lex > Glaze for VS. After surface finishing, the Total TP value of the VS material $(17.18 \pm 2.63)$ was found to be higher than that of the IPS material (15.55 \pm 1.93$)$. The ranking of the Total TP values after the surface finishing process from highest to lowest was Sof-lex > Glaze > Shofu for IPS and Shofu $>$ Glaze > Sof-lex for VS. The TP value for each group was different in terms of exposed solutions after surface finishing $(p<0.05)$. The highest TP value was demonstrated by the VS control group treated with Shofu (V3a) (TP: 21.36 \pm 0.07$)$. The lowest translucency 


\begin{tabular}{|c|c|c|c|c|c|c|c|c|c|c|c|}
\hline \multirow{2}{*}{ Material } & \multirow{2}{*}{$\begin{array}{l}\text { Method } \\
(n=10)\end{array}$} & \multicolumn{8}{|l|}{ Group } & \multirow{2}{*}{\multicolumn{2}{|c|}{ Total }} \\
\hline & & \multicolumn{2}{|l|}{ Control } & \multicolumn{2}{|l|}{ Cola } & \multicolumn{2}{|l|}{ Tea } & \multicolumn{2}{|l|}{ Coffee } & & \\
\hline \multirow{4}{*}{ IPS } & Glaze & $16.08 \pm 0.39$ & $(A, x, a)$ & $11.89 \pm 0.15$ & $(B, x, a)$ & $16.63 \pm 0.2$ & $(C, x, a)$ & $15.01 \pm 0.23$ & $(D, x, a)$ & $15.41 \pm 1.97$ & $(x, a)$ \\
\hline & Sof-lex & $18.41 \pm 0.2$ & $(A, x, b)$ & $12.58 \pm 0.11$ & $(B, x, b)$ & $15.33 \pm 0.14$ & $(C, x, b)$ & $16.05 \pm 0.12$ & $(D, x, b)$ & $16.08 \pm 2.13$ & $(x, b)$ \\
\hline & Shofu & $1.08 \pm 0.1$ & $(A, x, a)$ & $12.75 \pm 0.05$ & $(B, x, C)$ & $14.78 \pm 0.06$ & $(C, x, C)$ & $14.67 \pm 0.1$ & $(D, x, C)$ & $15.14 \pm 1.58$ & $(x, c)$ \\
\hline & Total & $16.6 \pm 1.15$ & $(A, x)$ & $12.41 \pm 0.39$ & $(B, x)$ & $15.58 \pm 0.8$ & $(C, x)$ & $15.24 \pm 0.62$ & $(D, x)$ & $15.55 \pm 1.93$ & $(x)$ \\
\hline \multirow{4}{*}{ VS } & Glaze & $18.54 \pm 0.08$ & $(A, y, a)$ & $18.19 \pm 0.1$ & $(B, y, a)$ & $19.62 \pm 0.1$ & $(C, y, a)$ & $15.88 \pm 0.08$ & $(D, y, a)$ & $17.12 \pm 2.26$ & $(y, a)$ \\
\hline & Sof-lex & $20.07 \pm 0.11$ & $(A, y, b)$ & $16.73 \pm 0.06$ & $(B, y, b)$ & $11.76 \pm 0.07$ & $(c, y, b)$ & $14.82 \pm 0.06$ & $(D, y, b)$ & $16.13 \pm 2.78$ & $(y, b)$ \\
\hline & Shofu & $21.36 \pm 0.07$ & $(A, y, c)$ & $17.65 \pm 0.11$ & $(B, y, c)$ & $14.98 \pm 0.1$ & $(c, y, c)$ & $16.86 \pm 0.07$ & $(D, y, c)$ & $18.3 \pm 2.41$ & $(y, c)$ \\
\hline & Total & $19.99 \pm 1.18$ & $(A, y)$ & $17.52 \pm 0.62$ & $(B, y)$ & $15.45 \pm 3.28$ & $(C, y)$ & $15.85 \pm 0.85$ & $(D, y)$ & $17.18 \pm 2.63$ & (y) \\
\hline \multirow[t]{4}{*}{ Total } & Glaze & $17.31 \pm 1.29$ & $(A, a)$ & $15.04 \pm 3.23$ & $(B, a)$ & $18.13 \pm 1.54$ & $(C, a)$ & $15.45 \pm 0.48$ & $(D, a)$ & $16.27 \pm 2.27$ & (a) \\
\hline & Sof-lex & $19.24 \pm 0.86$ & $(A, b)$ & $14.65 \pm 2.13$ & $(B, b)$ & $13.54 \pm 1.83$ & $(C, b)$ & $15.44 \pm 0.64$ & $(D, a)$ & $16.11 \pm 2.47$ & (b) \\
\hline & Shofu & $18.72 \pm 2.71$ & $(A, C)$ & $15.2 \pm 2.51$ & $(B, C)$ & $14.88 \pm 0.13$ & $(C, C)$ & $15.76 \pm 1.13$ & $(D, b)$ & $16.72 \pm 2.57$ & (c) \\
\hline & Total & $18.42 \pm 1.95$ & (A) & $14.96 \pm 2.63$ & (B) & $15.52 \pm 2.37$ & (C) & $15.55 \pm 0.8$ & (C) & $16.36 \pm 2.45$ & \\
\hline \multicolumn{12}{|c|}{$\begin{array}{l}\text { (ABCD): Intergroup comparison for interaction and main effects, (xy): Comparison of materials for interaction and main effects, (abc): Comparison } \\
\text { between methods for interaction and main effects, VS: Vita suprinity, IPS: IPS e.max cad }\end{array}$} \\
\hline
\end{tabular}

value was found in the VS group treated with Sof-Lex and exposed to black tea (V2c) (TP: $11.76 \pm 0.07)$. The translucency value of each material was generally statistically significant in terms of exposed solutions after the applied surface treatment $(p<0.05)$. The greatest decrease in TP values was observed in the IPS groups incubated in the cola solution. There was a statistically significant difference in TP values after exposure to colorant solutions for both materials $(p<0.05)$. The lowest TP value for the IPS group was observed in the samples exposed to cola, while, for the VS group, it was observed in the samples exposed to black tea.

\section{Discussion}

Based on the results of our work, the null hypotheses were rejected as the translucency of the monolithic CAD/CAM ceramics was affected by surface finishing and colorant solutions. Significant differences were shown among the ceramic groups for TP value.
Translucency is a very important factor in the selection of metal-free materials. Translucency is usually determined by CR or TP. Color determination in dentistry is done visually or instrumentally using spectrophotometers and colorimeters (35). Color measurements made with instruments indicate the potential to eliminate subjective errors in color evaluation and more importantly, are more sensitive when compared to the naked eye, without measuring the slight differences between the colors of colored objects on flat surfaces (36). During color measurement, both the true color of the surface and the lighting condition where the surface is measured affect the color that is measured (33). Therefore standard illuminant D65 was used in the study.

Color stability is as important as translucency in the long-term clinical success of ceramic restorations. Since researchers focus on the mechanical properties of ceramics, little is known about the color changes which occur over time in ceramic restorations. The absorption of colorants from external sources could 
cause staining in dental materials (37). Several studies have shown that nicotine (38), coffee and tea (39) were coloring solutions for polymeric materials. However, there is little research showing the effects of these liquids on ceramic surfaces. Surface roughness and surface finishing method have been shown to affect the paint ability of dental materials (37). Surface roughness has a direct effect on the sensitivity of the material to the extrinsic stain. However, finishing and polishing procedures, as well as the composition of the dental material, can affect the surface quality of the material; premature coloration is thought to be due to this (40). The purpose of this study was to observe the translucency change in monolithic glass ceramics exposed to cola, coffee, and black tea for six months. The effect of various surface finishing methods on the translucency of ceramics was also investigated.

Dental restorations should have a highly polished surface prior to use. If there is a rough surface on a restoration or prosthesis, food and other residues will stick to the rough surface. The ceramic surface is traditionally subjected to a surface treatment known as glaze. The glaze process closes the open pores on the surface after firing, providing better optical properties and more surface smoothness (41). At the same time, a smooth surface is formed to reduce biofilm accumulation (41). However, direct finishing and polishing methods on the restoration surface are widely used intraorally. Abrasive rubbers, aluminum oxide discs or diamond polishing paste combined with felt and silicone rubber discs can be used for this process. This procedure produces smooth surfaces, shortens the working time, and can be used to restore brightness after glaze processing, giving the restoration a more natural appearance (42). However, studies are lacking on the best finishing and polishing methods for VS and IPS ceramics to obtain a uniform ceramic surface. The Shofu abrasive tire system consists of ceramic polishing lacquer for prepolishing, ultra for polishing, and ultra II for a high gloss finish. Sof-lex discs are aluminum oxide discs. Polishing using small to large discs is performed. In our study, the groups which were finished with Soflex for IPS ceramics and were finished with Shofu for VS ceramics showed the highest TP values. The difference in the TP values could be the result of the different dimensions of the ceramic material crystals. At the same time, the distribution of crystals and the hardness of the material could affect the TP.

According to our results, statistically different TP values were determined for the different groups. The TP values of the ceramics ranged from 11.76 (V3b) to 21.36 (V1c). It was found that the TP value for the controls of the total VS material after surface treatment was higher than that of the controls of the total IPS material. Few studies have reported the TP values of the monolithic ceramics used in this study. In the present study, it was found that the TP value of the zirconia-reinforced glass-ceramic was higher than that of the lithium disilicate ceramic, similar to the findings of Awad et al. (43) and Sen and Us (44) studies. The researchers attributed this transparency difference to the fact that the lithium disilicate crystals in the lithium disilicate were four to eight times larger than those in the zirconium-reinforced glass-ceramics $(43,44)$. It has been reported that smaller crystals in the zirconia-reinforced lithium silicate glassy matrix of the ceramic exhibit better TP values due to the high glass content (43). In light of this information, we think that differences in TP values are responsible for the crystal content, grain size and microstructural differences in the materials.

To the best of the authors' knowledge, there is no study evaluating the TP of the specific ceramics used in our study after being kept in colorant solutions. The results of Ramakrishnaiah et al. (45) study showed an increase in the surface wettability and surface roughness of VS and IPS ceramics in direct proportion to the hydrofluoric acid etching time. In this study, generally the translucency value decreased in the groups treated with cola, coffee, and black tea for both VS and IPS groups according to the control groups. The lowest TP value for the IPS group was observed in the samples exposed to cola, while for the VS group it was observed in the samples exposed to tea. Cola, tea and coffee are acidic liquids (46). It is thought that this decrease in translucency may be because of the increased wettability of the ceramics as a result of the increase in the roughness of the ceramics due to the acidic effects of cola, coffee, and black tea. al-Hiyasat et al. (47) reported that cola abrades various ceramics and that this erosion can lead to a tribochemical corrosion mechanism. Crispin and Caputo (18) have shown that significant color change occurs on rough surfaces. The decrease in TP values after treatment with cola, coffee, and black tea indicates that these 
solutions cause color change on the VS and IPS ceramics. It is reported that theaflavins in tea leaves cause color change. Likewise, caffeine and caffeic acid cause a color change in the materials (48).

\section{Study Limitation}

One limitation of this study is that the investigation was carried out under in vitro conditions. Further in vivo studies are required to simulate clinical conditions for TP of VS and IPS ceramics.

\section{Conclusions}

Within the limitations of this study, the following conclusions were drawn. The translucency was affected according the monolithic CAD/CAM ceramic type. The translucency of the zirconia-reinforced glassceramic was found to be higher than that of the lithium disilicate glass-ceramic. Colorant solutions decreased the translucency of both VS and IPS ceramics. The lowest TP value for the IPS group was observed in the samples exposed to cola, while, for the VS group, it was observed in the samples exposed to black tea. According to the results of this study, IPS ceramics finished with Sof-Lex and VS ceramics finished with Shofu exhibited higher translucency values.

\section{Ethics}

Ethics Committee Approval: The ethics committee approval was not necessary since the study was in vitro.

Informed Consent: This study is a laboratory study. Therefore, patient consent is not required.

Peer-review: Externally peer-reviewed

\section{Authorship Contributions}

Concept: Y.H., I.S., Design: Y.H., I.S., Data Collection or Processing: Y.H., I.S., Analysis or Interpretation: Y.H., I.S., Literature Search: Y.H., Writing: Y.H.

Conflict of Interest: No conflict of interest was declared by the authors.

Financial Disclosure: The authors declared that this study received no financial support.

\section{References}

1. Heffernan MJ, Aquilino SA, Diaz-Arnold AM, Haselton DR, Stanford CM, Vargas MA. Relative translucency of six all-ceramic systems. Part I: core materials. J Prosthet Dent 2002; 88: 4-9.

2. Lopes GC, Baratieri LN, Caldeira de Andrada MA, Maia HP. Allceramic post core, and crown: technique and case report. J Esthet Restor Dent 2001; 13: 285-95.
3. Jarad FD, Russell MD, Moss BW. The use of digital imaging for colour matching and communication in restorative dentistry. $\mathrm{Br}$ Dent J 2005; 199: 43-9.

4. Wee AG, Chen WY, Johnston WM. Color formulation and reproduction of opaque dental ceramic. Dent Mater 2005; 21: 665-70.

5. Clark EB. Selection of tooth color for the edentulous patient. J Am Dent Assoc 1947; 35: 787-93.

6. Preston JD. Current status of shade selection and color matching. Quintessence Int 1985; 16: 47-58.

7. Brodbelt RH, O'Brien WJ, Fan PL. Translucency of dental porcelains. J Dent Res 1980; 59: 70-5.

8. O'Keefe KL, Pease PL, Herrin HK. Variables affecting the spectral transmittance of light through porcelain veneer samples. J Prosthet Dent 1991; 66: 434-8.

9. Watts DC, Cash AJ. Analysis of optical transmission by $400-500$ $\mathrm{nm}$ visible light into aesthetic dental biomaterials. J Dent 1994; 22: 112-7.

10. ten Bosch JJ, Coops JC. Tooth color and reflectance as related to light scattering and enamel hardness. J Dent Res 1995; 74: 374-80.

11. Paul SJ, Pliska P, Pietrobon N, Schärer P. Light transmission of composite luting resins. Int J Periodontics Restorative Dent 1996; 16: 164-73.

12. Arikawa $H$, Fujii $K$, Kanie $T$, Inoue K. Light transmittance characteristics of light-cured composite resins. Dent Mater 1998; 14: 405-11.

13. Chen YM, Smales RJ, Yip KH, Sung WJ. Translucency and biaxial flexural strength of four ceramic core materials. Dent Mater 2008; 24: 1506-11.

14. Johnston WM. Review of translucency determinations and applications to dental materials. J Esthet Restor Dent 2014; 26: 217-23.

15. Cho MS, Lee YK, Lim BS, Lim YJ. Changes in optical properties of enamel porcelain after repeated external staining. J Prosthet Dent 2006; 95: 437-43.

16. Weitman RT, Eames WB. Plaque accumulation on composite surfaces after various finising procedures. J Am Dent Assoc 1975; 91: 101-6.

17. Jefferies SR. The art and science of abrasive finishing and polishing in restorative dentistry. Dent Clin North Am 1998; 42: 613-27.

18. Crispin BJ, Caputo AA. Color stability of temporary restorative materials. J Prosthet Dent 1979; 42: 27-33.

19. Han GJ, Kim JH, Lee MA, Chae SY, Lee YH, Cho BH. Performance of a novel polishing rubber wheel in improving surface roughness of feldspathic porcelain. Dent Mater J 2014; 33: 739-48.

20. Holloway JA, Miller RB. The effect of core translucency on the aesthetics of all-ceramic restorations. Pract Periodontics Aesthet Dent 1997; 9: 567-74.

21. Seghi RR, Johnston WM, O'Brien WJ. Spectrophotometric analysis of color differences between porcelain systems. J Prosthet Dent 1986; 56: 35-40.

22. Denry I, Kelly JR. Emerging ceramic-based materials for dentistry. J Dent Res 2014; 93: 1235-42. 
23. Thompson JY, Stoner BR, Piascik JR, Smith R. Adhesion/ cementation to zirconia and other non-silicate ceramics: where are we now? Dent Mater 2011; 27: 71-82.

24. Elsaka SE. Influence of surface treatments on the surface properties of different zirconia cores and adhesion of zirconiaveneering ceramic systems. Dent Mater 2013; 29: e239-51.

25. Culp L, McLaren EA. Lithium disilicate: the restorative material of multiple options. Compend Contin Educ Dent 2010; 31: 716-20, $722,724-5$.

26. Lee YK. Changes in the translucency of porcelain and repairing resin composite by the illumination. Dent Mater 2007; 23: 4927.

27. Wendler M, Belli R, Petschelt A, Mevec D, Harrer W, Lube T, et al. Chairside CAD/CAM materials. Part 2: Flexural strength testing. Dent Mater 2017; 33: 99-109.

28. Kelly JR, Benetti P. Ceramic materials in dentistry: historical evolution and current practice. Aust Dent J 2011; 56(Suppl 1): 84-96.

29. Quinn JB, Sundar V, Lloyd IK. Influence of microstructure and chemistry on the fracture toughness of dental ceramics. Dent Mater 2003; 19: 603-11.

30. Belli R, Geinzer E, Muschweck A, Petschelt A, Lohbauer U. Mechanical fatigue degradation of ceramics versus resin composites for dental restorations. Dent Mater 2014; 30: 42432.

31. Kang SH, Chang J, Son HH. Flexural strength and microstructure of two lithium disilicate glass ceramics for CAD/CAM restoration in the dental clinic. Restor Dent Endod 2013; 38: 134-40.

32. Elsaka SE, Elnaghy AM. Mechanical properties of zirconia reinforced lithium silicate glass-ceramic. Dent Mater 2016; 32: 908-14.

33. Guler AU, Yilmaz F, Kulunk T, Guler E, Kurt S. Effects of different drinks on stainability of resin composite provisional restorative materials. J Prosthet Dent 2005; 94: 118-24.

34. Skyllouriotis AL, Yamamoto HL, Nathanson D. Masking properties of ceramics for veneer restorations. J Prosthet Dent 2017; 118: 517-23.
35. Joiner A. Tooth colour: a review of the literature. J Dent 2004; 32(Suppl 1): 3-12.

36. William JO. Dental materials and their selection, 3rd ed. Canada: Quint Pub Inc, 2002: 28.

37. Um CM, Ruyter IE. Staining of resin-based veneering materials with coffee and tea. Quintessence Int 1991; 22: 377-86.

38. Raptis CN, Powers JM, Fan PL, Yu R. Staining of composite resins by cigarette smoke. J Oral Rehabil 1982; 9: 367-71.

39. Gross MD, Moser JB. A colorimetric study of coffee and tea staining of four composite resins. J Oral Rehabil 1977; 4: 311-22.

40. Türkün LS, Türkün $M$. Effect of bleaching and repolishing procedures on coffee and tea stain removal from three anterior composite veneering materials. J Esthet Restor Dent 2004; 16 : 290-301.

41. al-Wahadni A, Martin DM. Glazing and finishing dental porcelain: a literature review. J Can Dent Assoc 1998; 64: 580-3.

42. Ward MT, Tate WH, Powers JM. Surface roughness of opalescent porcelains after polishing. Oper Dent 1995; 20: 106-10.

43. Awad D, Stawarczyk B, Liebermann A, Ilie N. Translucency of esthetic dental restorative CAD/CAM materials and composite resins with respect to thickness and surface roughness. J Prosthet Dent 2015; 113: 534-40.

44. Sen N, Us YO. Mechanical and optical properties of monolithic CAD-CAM restorative materials. J Prosthet Dent 2018; 119: 5939.

45. Ramakrishnaiah R, Alkheraif AA, Divakar DD, Matinlinna JP, Vallittu PK. The Effect of Hydrofluoric Acid Etching Duration on the Surface Micromorphology, Roughness, and Wettability of Dental Ceramics. Int J Mol Sci 2016; 17: E822.

46. Feldman $M$, Barnett $C$. Relationships between the acidity and osmolality of popular beverages and reported postprandial heartburn. Gastroenterology 1995; 108: 125-31.

47. al-Hiyasat AS, Saunders WP, Sharkey SW, Smith GM. The effect of a carbonated beverage on the wear of human enamel and dental ceramics. J Prosthodont 1998; 7: 2-12.

48. Keskin IS. The treatment of prosthetic dental materials with hypochlorite. Ankara: Middle East Technical Univ. 2002. 